\title{
'A Community Patent, A Community Intellectual Property Court and the Tower of Babel'
}

Citation for published version (APA):

Kamperman Sanders, A. W. J. (2001). 'A Community Patent, A Community Intellectual Property Court and the Tower of Babel'. Maastricht Journal of European and Comparative Law, 227.

https://doi.org/10.1177/1023263X0100800301

Document status and date:

Published: 01/01/2001

DOI:

10.1177/1023263X0100800301

Document Version:

Publisher's PDF, also known as Version of record

Document license:

Taverne

Please check the document version of this publication:

- A submitted manuscript is the version of the article upon submission and before peer-review. There can be important differences between the submitted version and the official published version of record.

People interested in the research are advised to contact the author for the final version of the publication, or visit the DOI to the publisher's website.

- The final author version and the galley proof are versions of the publication after peer review.

- The final published version features the final layout of the paper including the volume, issue and page numbers.

Link to publication

\footnotetext{
General rights rights.

- You may freely distribute the URL identifying the publication in the public portal. please follow below link for the End User Agreement:

www.umlib.nl/taverne-license

Take down policy

If you believe that this document breaches copyright please contact us at:

repository@maastrichtuniversity.nl

providing details and we will investigate your claim.
}

Copyright and moral rights for the publications made accessible in the public portal are retained by the authors and/or other copyright owners and it is a condition of accessing publications that users recognise and abide by the legal requirements associated with these

- Users may download and print one copy of any publication from the public portal for the purpose of private study or research.

- You may not further distribute the material or use it for any profit-making activity or commercial gain

If the publication is distributed under the terms of Article $25 \mathrm{fa}$ of the Dutch Copyright Act, indicated by the "Taverne" license above, 


\section{HEINONLINE}

DATE DOWNLOADED: Mon Sep 13 05:19:12 2021

SOURCE: Content Downloaded from HeinOnline

Citations:

Bluebook 21st ed.

Anselm Kamperman Sanders, A Community Patent, a Community Intellectual Property Court and the Tower of Babel, 8 Maastricht J. EUR. \& COMP. L. 227 (2001).

ALWD 6th ed.

Kamperman Sanders, A. ., A community patent, a community intellectual property court and the tower of babel, 8(3) Maastricht J. Eur. \& Comp. L. 227 (2001).

APA 7th ed.

Kamperman Sanders, A. (2001). community patent, community intellectual property court and the tower of babel. Maastricht Journal of European and Comparative Law, 8(3), 227-232.

Chicago 17th ed.

Anselm Kamperman Sanders, "A Community Patent, a Community Intellectual Property Court and the Tower of Babel," Maastricht Journal of European and Comparative Law 8, no. 3 (2001): 227-232

McGill Guide 9th ed.

Anselm Kamperman Sanders, "A Community Patent, a Community Intellectual Property Court and the Tower of Babel" (2001) 8:3 Maastricht J Eur \& Comp L 227.

AGLC 4th ed.

Anselm Kamperman Sanders, 'A Community Patent, a Community Intellectual Property Court and the Tower of Babel' (2001) 8(3) Maastricht Journal of European and Comparative Law 227.

MLA 8th ed.

Kamperman Sanders, Anselm. "A Community Patent, a Community Intellectual Property Court and the Tower of Babel." Maastricht Journal of European and Comparative Law, vol. 8, no. 3, 2001, p. 227-232. HeinOnline.

OSCOLA 4th ed.

Anselm Kamperman Sanders, 'A Community Patent, a Community Intellectual Property Court and the Tower of Babel' (2001) 8 Maastricht J Eur \& Comp L 227

Provided by:

Maastricht University Library

-- Your use of this HeinOnline PDF indicates your acceptance of HeinOnline's Terms and Conditions of the license agreement available at

https://heinonline.org/HOL/License

-- The search text of this PDF is generated from uncorrected OCR text.

-- To obtain permission to use this article beyond the scope of your license, please use: 


\section{A Community Patent, a Community Intellectual Property Court and the Tower of Babel}

For the EC Stockholm Summit of 23-24 March 2001, the Commission noted ${ }^{1}$ that progress on the Community patent had been too slow. The single Community patent, first envisaged in the Community Patent Convention, has lain dormant for years. ${ }^{2}$ The positive experience with the unitary Community Trade Mark, ${ }^{3}$ as well as heavy industry pressure had persuaded the Commission and Member States that a unitary patent right for the Community would be instrumental in the enhancement of the EU's competitiveness. A Commission Proposal for Council Regulation on the Community Patent had already been presented in August 2000, ${ }^{4}$ but further necessary negotiations dealing inter alia with the link between the Regulation on the Community patent and the European Patent Organization, translation costs, and language arrangements exposed the old rifts and difficulties that have dogged the inception of the Community patent for years.

Presently the European patent system is governed by the Munich Convention of $1973,^{5}$ which lays down a single procedure for the granting of patents by the European Patent Office (EPO) in Munich. However, once the European patent has been granted, it becomes a national patent and is subject to the national rules of the contracting States designated in the application. A single European application therefore leads to a bundle of national patents. This also explains the problem with the current system, in that costs

1. Vide $\operatorname{COM}(2001) 79$ final, at:

http://europa.eu.int/eur-lex/en/com/cnc/2001/act79en02/com2001_0079en02-01.pdf (visited on 03-092001).

2. Convention for the European Patent for the common market of 15 December 1975 (Community Patent Convention, or CPC).

3. Council Regulation (EC) No. $40 / 94$ of 20 December 1993 on the Community Trade Mark, [1994] O.J. L11.

4. Commission Proposal - $\operatorname{COM}(2000) 412$ final.

5. Convention on the Grant of European Patents of 5 October 1973 (European Patent Convention, or EPC). 
and lack of legal certainty for applicants and rightholders are inflated by translation costs, enforcement on a country-by-country basis, diverging standards of procedure, and diverging judgments. ${ }^{6}$ This means that the European patent is expensive. More significantly, it is five times more expensive than equivalent patents in the US and Japan. $^{7}$ On average the cost of obtaining a patent in the member states to the European Patent Convention (EPC) is $€ 49.900$. In the US an equivalent patent costs $€ 10.330$, and in Japan $€ 16.350$.

Of the total average cost for a European patent, ${ }^{8} 14 \%$ is taken up by the EPO fees, ${ }^{9}$ and $18 \%$ for professional representation before the EPO. ${ }^{10}$ At national level $29 \%$ of the costs is spent on renewal fees for national IP offices for the $5^{\text {th }}$ to the $10^{\text {th }}$ year. ${ }^{11}$ Translation fees, however, make up a whopping $39 \%$ of the total costs. ${ }^{12}$

The EPC is governed by conventional international law and does not form part of the Community legal order. Moreover, nineteen countries are members of the European Patent Organization, comprising the EC Member States, but also non-EC members Switzerland, Liechtenstein, Monaco and Cyprus. With Turkey about to join and Bulgaria, the Czech Republic, Estonia, Hungary, Poland, Romania, Slovakia and

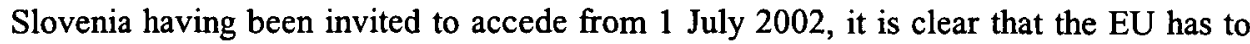
follow the contours of the EPC, and heed the wishes and demands of all members of the European Patent Organization. The Community Patent therefore is only viable if it ties in with the European Patent Convention. Furthermore for both the amended European and new Community patent regimes to be competitive compared to other systems, a cost reduction has to be achieved in those areas that make the current European Patents

6. See the Epilady decisions (1993) 24 IIC 803, 823, in which a diverging standard for the test for equivalents (EPC Art. 69) led to different outcomes in several participating countries in similar actions deriving form a single EPO patent.

7. Comparative table of costs and fees (in euros) payable for obtaining patents in the EU, the United States and in Japan (source: EC Commission http://europa.eu.int/comm/internal_market/en/indprop/2k714.htm\#l (as visited 20-09-2001)):

\begin{tabular}{|l|c|c|c|c|c|c|c|}
\hline & $\begin{array}{l}\text { Filing and } \\
\text { search fees }\end{array}$ & $\begin{array}{l}\text { Examina- } \\
\text { tion fees }\end{array}$ & Grant fees & $\begin{array}{c}\text { Renewal } \\
\text { fees }\end{array}$ & $\begin{array}{c}\text { Translation } \\
\text { costs }\end{array}$ & $\begin{array}{c}\text { Agent's } \\
\text { fees }\end{array}$ & Total \\
\hline $\begin{array}{l}\text { EPC } \\
\text { (typical } \\
\text { application, } \\
8 \text { Member } \\
\text { States) }\end{array}$ & $€ 810+€ 532$ & $€ 1431$ & $€ 715$ & $€ 16790$ & $€ 12600$ & $€ 17000$ & $€ 49900$ \\
\hline US & $€ 690$ & - & $\epsilon 1210$ & $€ 2730$ & n/a & $€ 5700$ & $€ 10330$ \\
\hline Japan & $€ 210$ & $\epsilon 1100$ & $€ 850$ & $€ 5840$ & n/a & $€ 8450$ & $€ 16450$ \\
\hline
\end{tabular}

8. $€ 29800$ in 8 states over a 10 year term at 01-07-1999 (source: EPO).

9. $€ 4300$, of which $€ 800$ for filing, $€ 2400$ for examination, and $€ 1100$ for grant (source: EPO).

10. $€ 5500$ (source: EPO).

11. $€ 8500$ (source: EPO)

12. $€ 11500$ (source: EPO). 
so unattractive. This means a reduction in the translation costs, as well as a unified application and enforcement procedure. The result of the diplomatic conference of 2029 November 2000 on the revision of the $\mathrm{EPC}^{13}$ can be seen as an important milestone in bringing about the necessary changes for the European patent system and the inception of the Community patent.

Currently an application for a European Patent is made in the European Patent Office, designating the countries for which the applicant desires to hold patents. The application may be prosecuted before the office in one of its official languages: English, German and French. For a grant to be made, the claims have to be translated into the other official languages of the office, but once the patent is granted, it will also be translated into the local official language of each designated country. The revised EPC now also envisages a system whereby states party to the Agreement having a national language in common with one of the official languages of the EPO will not require translation of the European patent. Other EPC states will not require a translation if the European patent is granted in an EPO official language which that state has indicated to be its language of choice, or if a translation of the European patent in that language is filed with the national office. Translation of the European patent into the national language may be required in respect of the claims only. Full translation of a European patent may only be required by EPC states upon enforcement or litigation of the patent, so as to safeguard the interests of the defendant. So far the agreement has been signed by nine EPC states. $^{14}$

As the proposed Community patent envisages a unitary patent granted by the EPO under the EPC, it can now follow the application contours and language regime of the revised EPC. The Community Patent requires an application in one of the official languages of the EPO, and translation of the claims into the two other languages only. ${ }^{15}$ Because of its unitary character, one set of fees is payable on grant and on renewal. Through accession of the EU to the European patent system, the examination, grant, and renewal phase is out-sourced to the European Patent Organization, but Community law governs the autonomous post-grant regime. To emphasize the unitary character of the

13. Special edition No. 1 of the Official Journal 2001 of the European Patent Office.

14. (CH, BRD, DK, LI, LU, MC, NL, SE, UK). Entry into force will be after ratification by 8 states, including $\mathrm{BRD}, \mathrm{FR}, \mathrm{UK}$.

15. See 'The Community Patent - Frequently Asked Questions', available at:

http://europa.eu.int/comm/internal_market/en/indprop/2k-41.htm\#6 (as visited 20-09-2001): "The linguistic regime (from application, examination, grant until publication) is pre-determined by the choice to adhere to the EPC. This means that the application will be examined, granted and published in one of the three working languages of the EPO (English, French, German) with a translation of the claims in the two other working languages. This regime is applicable to European Patents and the Community Patents alike as the Community Patent is nothing more than a European Patent requested for the whole of the EC territory. The only choice that is made is that, in contrast to the EPC, an option for Member States to ask for additional translations in their own language is not foreseen. The Community Patent is deemed to be directly valid for the whole of the Community on the basis of the patent as granted by the EPO.' 
Community patent a Community Intellectual Property Court (CIPC) of first instance, as well as a Community Intellectual Property Court of Appeal (CIPCoA) will be created to try actions for infringement and revocation of Community patents. This combination between infringement and validity issues has been included, because almost every claim for infringement will immediately prompt the defendant to raise a counterclaim for invalidity of the patent. However not all disputes will be settled in one procedure, as the Regulation provides that all disputes between private parties which do not specifically come under the jurisdiction of the centralized court, such as inter alia the right to the patent, the transfer of the patent or contractual licenses, are to be dealt with by the national courts of the Member States. The CIPC may be addressed to obtain panCommunity provisional and protective measures, with a possibility for full appeal to the CIPCoA, all in accordance with the rules of jurisdiction contained in the Brussels Convention. This means that decisions from the CIPC and CIPCoA are enforceable, and because of the unitary character of the Community patent, will have equal effect throughout the EU. The European Court of Justice will retain its position in respect of the construction of an interpretation of the Regulation. Whereas the CIPCoA is set to be a centralized institution, the CIPC may sit in various localities, the multitude and location of which are likely to be determined by the bargaining process currently taking place over the loss of languages in which a Community patent will be published. Most notably Spain, Portugal, Italy, Greece, and Belgium have raised objections over the language issue. Furthermore following the slicing, packaging and labeling cases involving the protection of designations of origin and geographical indication, the direct effect of legal instruments made pursuant to a regulation are called into question if they are not published in the official language of the country in which they are to be enforced. This Regulation ${ }^{16}$ creates a procedure by which the Commission can register a name that satisfies specified criteria as a 'protected designation of origin' or a 'protected geographical indication'. A registered designation of origin or geographical indication is to enjoy protection in every Member State. In Consorzio per la Tutela del Formaggio Gorgonzola v Käserei Champignon Hofmeister $\mathrm{GmbH} \& \mathrm{Co} \mathrm{KG},{ }^{17}$ the European Court of Justice said that upon the registration of a protected designation of origin national rules ceased to apply and only the legal rules laid down in the Regulation on the protection of geographical indications (PGI) and designations of origin (PDO) are, together with the Treaty rules, relevant for the purpose of answering the questions about the scope of the protection of the protected denomination of origin. ${ }^{18}$ However, in Consorzio del Prosciutto di Parma v. Asda Stores Ltd., ${ }^{19}$ the House of Lords could not

16. Council Regulation (EEC) No 2081/92 of 14 July 1992 on the protection of geographical indications and designations of origin.

17. Case C-87/97 Consorzio per la Tutela del Formaggio Gorgonzola v Käserei Champignon Hofmeister $\mathrm{GmbH}$ \& Co KG [1999] ECR I-1301.

18. Case C-87/97 Consorzio per la Tutela del Formaggio Gorgonzola v Käserei Champignon Hofmeister $G m b H \&$ Co $K G$ [1999] ECR I-1301, 1331, para. 18.

19. HL 08-02-2001 UKHL 7 available at: http://www.parliament.the-stationery-office.co.uk/pa/ld200001//djudgmt/jd010208/parmah-1.htm (As visited 17-09-2001). 
put to rest the question whether the Regulation on PGI and PDO has direct effect. The Court of Appeal had established that the specification containing the description of the product, in particular the requirements as to the packaging and labeling of sliced ham, had not been published in the Official Journal, or, for that matter, anywhere else. The Court of Appeal therefore raised the issue of transparency, in the sense that measures directly enforceable against citizens should be readily accessible. Although the description of the product is on file with the Commission, and could be released on the basis of the Commission Decision on public access to Commission documents, ${ }^{20}$ or could be requested from the association registering the protected designation of origin, it would in this case be in Italian. The judge in first instance and the Court of Appeal said that this was not good enough, and that a dealer in the U.K. should be able to ascertain from a readily accessible document in his own language precisely what products he was entitled to sell. ${ }^{21}$ This now means that preliminary questions have been put to the European Court of Justice on the direct effect of the Regulation on the protection of geographical indications and designations of origin and its derived legal instruments. ${ }^{22}$ The transparency problem was recognized in the Community Patent Regulation in that it enables rightholders to rely on the official languages to start proceedings, but in order to protect the interests of defendants in Member States with an official language other than that of the patent, damages can only be levied once the patent claims are translated into the official language of the country where the defendant is domiciled. ${ }^{23}$ It is interesting to note that the Commission deemed this necessary, as research indicates that only in a very limited number of cases translations of the common English text was asked for. ${ }^{24}$ The Regulation thus presupposes that

20. Commission Decision of 8 February 1994 on public access to Commission documents, [1994] O.J. L $46 / 58$.

21. Case C-87/97 Consorzio per la Tutela del Formaggio Gorgonzola v Käserei Champignon Hofmeister $\mathrm{GmbH} \&$ Co KG [1999] ECR I-1301, para. 37: 'Mr Green [who appeared for the respondents] painted an alarming picture of the difficulties of the comer grocer in obtaining and comprehending the 300 or so specifications, in a variety of Community languages, of products enjoying a PDO or PGI'.

22. The question put to the ECJ is: 'whether, as a matter of Community law, Council Regulation (EEC) No. 2081/92 read with Commission Regulation (EC) No 1107/96 and the specification for the PDO "prosciutto di Parma" create a valid Community right, directly enforceable in the court of a member state, to restrain the retail sale as "Parma ham" of sliced and packaged ham derived from hams duly exported from Parma in compliance with the conditions of the PDO but which have not been thereafter sliced, packaged and labelled in accordance with the specification.'

23. Case C-87/97 Consorzio per la Tutela del Formaggio Gorgonzola v Käserei Champignon Hofmeister $G m b H$ \& Co KG [1999] ECR I-1301, at 12, para 2.4.4: 'A translation could become necessary in legal proceedings against a suspected infringer. In such a situation, a suspected infringer who has been unable to consult the text of the patent in the official language of the Member State in which he is domiciled, is presumed, until proven otherwise, not to have knowingly infringed the patent. In order to protect a suspected infringer who, in such a situation, has not acted in a deliberate manner, it is provided that the proprietor of the patent will not be able to obtain damages in respect of the period prior to the translation of the patent being notified to the infringer.'

24. Case C-87/97 Consorzio per la Tutela del Formaggio Gorgonzola v Käserei Champignon Hofmeister $G m b H \&$ Co $K G$ [1999] ECR I-1301, n. 4 above at 12 para 2.4.4: 'The proposed system is regarded as appropriate, primarily because the universal language in the field of patents is, in reality, English. Translations are very rarely consulted. For example, at the Institut National de la Propriété 
untranslated patents are enforceable and have direct effect in the Member States. In the Parma Ham case European Court of Justice will have to determine whether and to what extent the language in which Community documents are accessible affects direct effect of Regulations and their instruments. The outcome of the Parma Ham case may therefore have an immediate effect on the viability of the Community Patent. As the Community patent falls within the same category as the registered designation of origin and geographical indication, its language regime will have to provide the same level of transparency. If the direct applicability over language issues were to be called into doubt, it would lead to the undesirable result that the adherence of the Community patent to the EPC would be jeopardized, for it would also undermine the new language regime of this latter convention. In that case the cost of language will translate itself into further delay and fragmentation.

Anselm Kamperman Sanders

Industrielle, the French national institute of industrial property rights, translations are consulted in only $2 \%$ of cases.' 